\title{
Experience of Mother in Taking Care of Children with Stunting at Majene Regency, Indonesia
}

\author{
Darwis Darwis ${ }^{1 *}$, Rukman Abdullah², Lili Amaliah ${ }^{3}$, Bohari Bohari ${ }^{3}$, Nurdin Rahman $^{4}$ \\ ${ }^{1}$ Department of Nursing, Nani Hasanuddin Health Science Academy, Makassar, Indonesia; ${ }^{2}$ Department of Medical Education, \\ Faculty of Medicine, Sultan Ageng Tirtayasa University, Serang, Indonesia; ${ }^{3}$ Department of Nutrition, Faculty of Medicine, \\ Sultan Ageng Tirtayasa University, Serang, Indonesia; ${ }^{4}$ Department of Nutrition, Faculty of Public Health, Tadulako University, \\ City of Palu, Indonesia
}

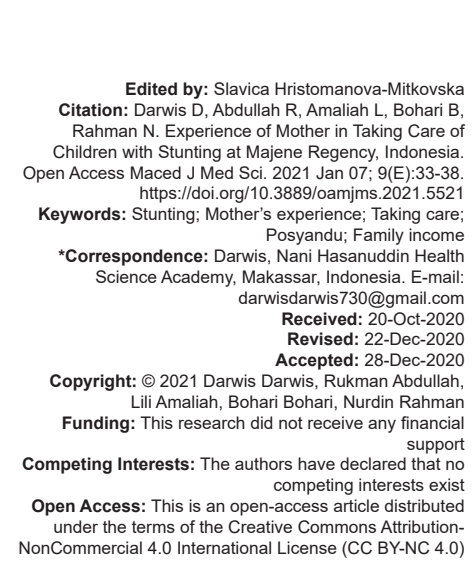

\begin{abstract}
BACKGROUND: Health officials have the role and responsibility to provide a promotive, preventive, curative, and rehabilitative action for children who are stunted. However, in fact, the role will be taken over entirely by parents, especially the mother. Therefore, the mother's experience needs to be explored to know the extent of a mother's efforts in treating her child who is stunted.

AIM: We aimed to explore mother's experiencein order to know the extent of a mother's efforts in caring for her child who is stunted.

MATERIALS AND METHODS: This research used a qualitative method with a phenomenological approach. Data were collected through deep interviews using a questionnaire that was prepared and then the researcher recorded the process of interview. The sampling technique used was purposive sampling then proceed with snowball sampling Then, data would be analyzed using the thematic analysis method.

RESULTS: Mothers of children who were categorized as stunting did not have clear knowledge about stunting performed exclusive breastfeeding for 6 months but breastfeeding was not optimal until the children are 2 years of age, complementary feeding was not balanced because it did not contain carbohydrate, protein, and fat sources, families with incomes below the minimum income experience stunted their children. Husband's support to all participants was very good in overcoming health problems that occur in children, but her husband's support was very lacking in efforts to prevent children from experiencing stunting, mothers of children who were categorized as stunting had good personal hygiene behaviors in children.

CONCLUSION: Health education about stunting with interactive and sustainable extension methods can increase
\end{abstract} the understanding of parents and families in caring for stunted children.

\section{Introduction}

Stunting is a chronic condition of malnutrition for a long time in a critical period of growth and development early in life. Stunting is defined as the percentage of children aged 0-59 months who are of height for ages under $<-2$ standard deviations (moderate and severe stunting) and -3 standard deviations (severe stunting) of the median [1]. Data from the United Nations International Children's Emergency Fund in April 2019 from estimates of joint malnutrition show that the prevalence of stunting has decreased since 2000, almost 1:4 of 149 million children under the age of 5 were stunted in 2018, and more than 49 million suffer from malnutrition [2].

Based on the 2015 PSG results, the prevalence of short toddlers in Indonesia is $29 \%$. This figure has decreased in 2016 to $27.5 \%$. However, the prevalence of short toddlers again increased to $29.6 \%$ in 2017. The prevalence of toddlers is very short and short at the age of 0-59 months in Indonesia in 2017 is $9.8 \%$ and $19.8 \%$. This condition increased from the previous year, in which the prevalence of very short toddlers was at $8.5 \%$ and short toddlers at $19 \%$. The province with the highest prevalence of toddlers who was very short and short at the age of 0-59 months in 2017 was East Nusa Tenggara, while the province with the lowest prevalence was Bali [3]. Riskesdas data in 2018, for children aged 0-23 months the short percentage was $24.5 \%$ and very short was $12.6 \%$, and for ages $0-59$ months the short percentage was $25.4 \%$ and very short was $16.0 \%$. West Sulawesi ranks second nationally [4].

Stunting affects the short and long term. The short-term impact is that motor, cognitive, and verbal development is not optimal and the incidence of illness and death increases so that it will also increase health costs. In the long term, it will have an impact on suboptimal posture in adulthood, an increased risk of disease and obesity, decreased reproductive health, reduced learning ability, and less optimal work productivity [5]. Factors that cause stunting are the provision of undernutrition in children, mothers who are in their adolescents experiencing malnutrition and during pregnancy, lack of optimal latency which affects 
the decline in body and brain growth, and low access to health services, sanitation, and clean water [5].

The contributing factors to stunting are lack of nutritious food intake [6], infectious diseases [7], and Health Services and Environmental Health [8]. With those factors, health officials have the role and responsibility to provide promotive, preventive, curative, and rehabilitative measures for children who are stunted. However, in fact, the role will be taken over entirely by parents, especially the mother. Therefore, the mother's experience needs to be explored to know the extent of a mother's efforts in caring for her child who is stunted.

\section{Methods}

This research used a qualitative method with a phenomenological approach. This research was carried out in Majene Regency in July 2019 and the research data collection began on July 15, 2019. Data were collected through deep interview using a questionnaire that was prepared and then recorded the process of interview the study population was all mothers with stunted children in the Totoli Community Health Center, Banggae District, Majene Regency. The sampling technique used was purposive sampling with minimum high school education criteria, could be invited to communicate for a long time, and has children with stunting. Then proceed with snowball sampling with a total sampling of 5 mothers in Pamboborang Village, Totoli Community Health Center, Banggae District, Majene Regency. Data would be analyzed using the thematic analysis method developed by Braun dan Clarke (2006). The stages consisted of (1) listening to recorded interviews, (2) understanding the data, (3) compiling the code to find the main thoughts, and (4) looking for themes [9].

\section{Results and Discussions}

\section{Characteristics of respondents}

All participants resided in the work area of the Totoli Public Health Center, especially in the village of Pamboborang, Banggae District, Majene Regency and according to the criteria desired in this research. In general, the informant's age is 20-35 years and has a high level of education with a number of children, 2-3 people (Table 1).

Table 1: Participant characteristics

\begin{tabular}{lllll}
\hline Informant & \multicolumn{3}{l}{ Characteristics } & \\
\cline { 2 - 5 } & Age & Education & Number of children & Children affected by stunting \\
\hline SP1 & 30 & High & 2 & Second \\
SP2 & 31 & High & 2 & First \\
SP3 & 22 & Middle & 2 & First \\
SP4 & 34 & High & 3 & Third \\
SP5 & 26 & High & 2 & First \\
\hline
\end{tabular}

Theme 1: What do you or your family know about stunting?

Based on what participant said in Table 2, the health officials have made an effort to conduct health education in the posyandu (integrated healthcare center). However, most mothers misunderstand information about stunting. A mother's understanding of stunting is a mismatch between age and weight. This misunderstanding results in that the mother not knowing that her child is stunted, which is the mismatch between age and height. The mothers who know about stunting are mothers who take counseling and pay close attention to explanations from health officials and realize that their children are stunted, so they try to get more information to overcome the problem of stunting in their children [10]. Wrong knowledge can trigger stunting in children [11].

Health officials should introduce this health problem in accordance with the language recognized by the community, especially mothers, stunting which is a foreign language that is still new and difficult for mothers to understand. Researchers carry out interactive and continuous counseling methods. Interactive means extension participants are directly involved in counseling so that the information delivered is not misunderstood. Continuity means that the provision of information does not stop at the health service, posyandu but is carried out until it reaches the family's home. The method can be in the form of giving brochures in the form of household items such as calendars, forming community-based stunting care groups that routinely discuss prevention, and handling stunting. Mother's knowledge must always be evaluated by conducting question and answer or surveys so that it is easy to identify mothers who lack of knowledge about stunting [12].

\section{Theme 2: Utilization of health services}

Table 3 shows that there are mother do not yet know the importance of utilizing health services as a means of information to prevent health problems, especially stunting. The closest primary health service in the mother's environment is posyandu. Posyandu is the most accessible facility for mothers to obtain health services. Posyandu consists of posyandu cadres who are people who have received posyandu cadre training and also attend 1-3 health workers. Activities in the Posyandu consist of weighing, documentation of the results of weighing and health consultations. Posyandu activities are carried out once every month [13].

For mothers who have stunted children, mothers rarely or never have access to health services and attend health education [14]. In the understanding of our society, posyandu only functions in the curative sphere. The family or mother takes her child to the posyandu or other health facilities only to treat her sick child [15]. The understanding of preventive is 
Table 2: Family know about stunting

\begin{tabular}{|c|c|c|}
\hline Code & Transcript & Description \\
\hline $\begin{array}{l}\text { What do you or your family know about stunting? } \\
\text { I got the information from the Health Care Worker } \\
\text { Counseling }\end{array}$ & $\begin{array}{l}\text { Yes, I know about stunting, I usually hear from Posyandu (Posyandu) or Puskesmas } \\
\text { (Public health center) counseling (SP1) } \\
\text { Yes, I know, the thing is, there has been a nutrition program for students, they gave it } \\
\text { to the students for } 7 \text { months because the target is for Pamboborang, the menu was } \\
\text { from the center (SP2) } \\
\text { "But once I was also informed, I knew about my son's health from Posyandu" (SP5) }\end{array}$ & $\begin{array}{l}\text { I got the information by visiting Posyandu and } \\
\text { Puskesmas, Posyandu is held once a month }\end{array}$ \\
\hline I know the meaning of stunting & "Stunting means children with impaired age with their height and weight" (SP 1) & $\begin{array}{l}\text { I know the meaning of stunting, that is, height } \\
\text { does not correspond to age }\end{array}$ \\
\hline I do not know the meaning of stunting & $\begin{array}{l}\text { "Stunting is the age does not correspond to body weight" (SP 2) } \\
\text { "I do not know what stunting is" (SP 3) } \\
\text { "What's that, Stunting" (SP 4) } \\
\text { "Stunting, that's what the scales are lacking" (SP 5) }\end{array}$ & $\begin{array}{l}\text { I do not know the meaning of stunting, so I do } \\
\text { not know that my child is experiencing stunting }\end{array}$ \\
\hline I have never attended health education for stunting & $\begin{array}{l}\text { "I do not know, I also have never participated in counseling at Posyandu" (SP3) } \\
\text { "I have never heard of what it says stunting, I do not know that either" (SP4) }\end{array}$ & $\begin{array}{l}\text { I have never attended health counseling } \\
\text { held by health workers at Posyandu and } \\
\text { Puskesmas }\end{array}$ \\
\hline
\end{tabular}

Table 3: Utilization of health services

\begin{tabular}{|c|c|c|}
\hline Code & Transcript & Description \\
\hline \multicolumn{3}{|c|}{ How do you use health services to find out about stunting? } \\
\hline $\begin{array}{l}\text { I utilize health services for getting information about } \\
\text { stunting }\end{array}$ & $\begin{array}{l}\text { "While coming to the Posyandu, I hear about this counseling" (SP 1) } \\
\text { "I always take my child to Posyandu" (SP 2) }\end{array}$ & $\begin{array}{l}\text { I utilize health care facilities as a source of information and } \\
\text { treatment for various diseases, especially stunting }\end{array}$ \\
\hline I take my child to the health center if they are sick & $\begin{array}{l}\text { "I usually take my child to Puskesmas when he is sick" } \\
\text { "I usually take him to the health center if he gets sick" }\end{array}$ & I use health services if my child is sick \\
\hline $\begin{array}{l}\text { I do not utilize health services for getting information } \\
\text { about stunting }\end{array}$ & $\begin{array}{l}\text { "Usually there is counseling at Posyandu but I do not attend it, I rarely } \\
\text { take my child to Posyandu" (SP 3) }\end{array}$ & $\begin{array}{l}\text { I do not yet know the importance of utilizing health services } \\
\text { as a means of information to prevent health problems, } \\
\text { especially stunting }\end{array}$ \\
\hline
\end{tabular}

only limited to immunization. In fact, posyandu is the foremost source in obtaining health information for preventing disease (preventive) [16].

\section{Theme 3: Fulfillment of nutrition and ASI} (breastfeeding) in Children

Table 4 shows that the mother maintains the hygiene of their children by paying attention to personal hygiene every day at least bathing twice a day, but there are mothers do not give breast milk until the age of 2 years because of interference with the breast so that milk production is low, and the mother does not provide complementary foods consisting of carbohydrates, protein, and fat.

Most apply exclusive breastfeeding at the age of 0-6 months. However, breastfeeding does not continue optimally until children are 2-years-old. WHO and UNICEF (2003) that is to reduce infant and child morbidity mortality can be done by giving exclusive breastfeeding given at the age of the $1^{\text {st }} 6$ months of life, and adequate nutrition according to the body's needs, using native and local food ingredients up to the age of 2 years or more [17], [18].

All mothers have applied exclusive breastfeeding, namely breastfeeding to infants without additional food from 0 months to 6 months. All mothers have realized the importance of exclusive breastfeeding for children's health. However, breastfeeding is not done until the child is 2-years-old. Most mothers experience a decrease in the amount of breast milk at the age of 4 months to 1 year. The decrease in the amount is caused by a lack of nutrition from the mother. In nursing mothers, it is recommended to add 400-600 kcal/day of nutrient intake to support optimal milk production throughout the day. Providing complementary feeding
(MP-ASI) most mothers have done it right. The health service has tried to introduce the composition of the MP ASI (complementary feeding) balanced nutrition for children with the nutritional program providing balanced nutrition MPASI (complementary feeding). There are still mothers who give MP ASI in the form of carbohydrate sources, even though protein and fat cannot be ignored. Health officials have introduced eggs and green beans as a source of protein and fat that are cheap and easy to get around the mother's environment. This gift is intended so that mothers and families can imitate the menu in providing daily food for children.

Information from interviews also shows that children prefer to eat snacks and tend to refuse homebased food (Table 4). This happens because children are immediately introduced to snacks before the age exceeds 2 years. So that the golden period of growth and development of a child's baby that is the $1^{\text {st }} 1000$ days the child becomes disrupted [19]. Lack of maternal knowledge about substitute food sources also affects here, for example, carbohydrate sources, according to the mother can only be obtained from rice even though it can be filled through potatoes and bread. Providing additional food in the $1^{\text {st }} 1000$ days greatly supports the growth and development of children at a later age [20].

There is a program that can be applied so that there are changes in eating behavior in families, especially children. Plant the seed had a positive impact on factors associated with healthy eating behavior. This program demonstrates how to effectively engage community resources, to promote the development and implementation of gardening environments that create hands-on opportunities for children to become directly connected to local food production, to learn about the environmental benefits of eating locally grown foods, and to allow children to have access to a positive, sustainable food environment [21]. 


\section{Theme 4: Financial of family}

Table 5 shows that most of the informants have income $<$ Rp. $1,000,000$ but the level of income is sufficient to meet the nutritional needs of the family. Income influences the incidence of stunting; income that is less than the regional minimum standard will reduce the ability of families to provide nutritious food for all family members which also impacts children. Families who earn income below the regional minimum income have a risk of 6625 times greater chance of their children experiencing stunting compared to families with the same income or more than the regional minimum income [22].
Income is also one of the factors in efforts to build family nutrition [23]. In addition, in an effort to maintain and improve family nutrition, awareness of all family members is needed in prioritizing the use of income to improve family nutrition. This is not easy, because the family has other needs that they think are no less important. However, if the family can get to know sources of nutrition that is cheap and easily accessible, this can be achieved. For this reason, health officials should introduce to families and the wider community about food sources that are of high nutritional value but cheap and easy to obtain [24]. Inclusion should ideally be used to build a family to be

Table 4 :Fulfillment of nutrition and ASI (breastfeeding) in children

\begin{tabular}{|c|c|c|}
\hline Code & Transcript & Description \\
\hline \multicolumn{3}{|c|}{ How is the hygiene of your child every day and how do you maintain the hygiene of your child? } \\
\hline I keep my child's hygiene well & $\begin{array}{l}\text { "That's all, take a bath and wash hands and eat. Moreover, the bath is } 2 \text { times a day" } \\
\text { (SP 1) } \\
\text { "The shower is the same in the morning and the afternoon" (SP 2) } \\
\text { "Take a bath } 3 \text { times a day but he sometimes takes a bath twice a day" (SP 3) } \\
\text { "He takes a shower in the morning and afternoon" (SP 4) } \\
\text { "Always } 2 \text { times a day" (SP 5) }\end{array}$ & $\begin{array}{l}\text { I maintain the hygiene of my children by } \\
\text { paying attention to personal hygiene ever } \\
\text { day at least bathing twice a day }\end{array}$ \\
\hline \multicolumn{3}{|c|}{ Could you tell me about how you breastfeeding your child so far? } \\
\hline $\begin{array}{l}\text { I breastfeed my child until he/she is at the age } \\
\text { of } 2 \text { years }\end{array}$ & "Stop breastfeeding when my child is more than 3 years old" (SP 3 ) & $\begin{array}{l}\text { Breast milk is given until the age of } 2 \\
\text { years without interruption }\end{array}$ \\
\hline I apply exclusive breastfeeding & $\begin{array}{l}\text { "Breastfeeding for } 6 \text { months" (SP 2) } \\
\text { "Breastfeeding until my child is at the age of } 7 \text { months" (SP 3) } \\
\text { "Still breastfeeding until now" (SP } 4 \text { ) } \\
\text { "One year of quitting giving breast milk" (SP 5) }\end{array}$ & $\begin{array}{l}\text { Breast milk is given to children from } 0-6 \\
\text { months of age without providing other } \\
\text { foods }\end{array}$ \\
\hline $\begin{array}{l}\text { I do not give my child breast milk until the age of } \\
2 \text { years, because the low breast milk supply }\end{array}$ & $\begin{array}{l}\text { "Almost } 1 \text { year old, there is no breast milk comes out yet" (SP } 2) \\
\text { "One year to stop breastfeeding, the baby does not want to drink breast milk because I } \\
\text { used to have boils" (SP } 5 \text { ) }\end{array}$ & $\begin{array}{l}\text { I do not give breast milk until the age of } \\
2 \text { years because of interference with the } \\
\text { breast so that milk production is low }\end{array}$ \\
\hline
\end{tabular}

(a)

of nutrition to your baby so far and is there any additional nutrition provided by the health service to your baby?
baby does not want to eat, prefers to eat snacks

MP-ASI (complementary food) consists of carbohydrate, protein, and fat sources

MP-ASI (complementary foods) consists of carbohydrate, protein, and fat sources

I was exposed to the introduction and delivery of MP-ASI (complementary foods) balanced nutrition program from the Health Facility

I did not get exposed to the introduction and delivery of MP-ASI (complementary foods) balanced nutrition program from the Health Facility like eating crackers, or buying food from the street vendor" (SP 3 )

"Too lazy to eat" (SP 4 )

"Very poor appetite" (SP 5)

"He lost his appetite, he only eats a little" (SP 2 )

"The age of 6 months to 1 year, the baby ate sun porridge as well as breast milk, one box of the sun porridge used to run out within 3 days. I regularly gave the baby porridge after bathing in the morning, afternoon, and evening, and at the age of 1 year, the baby only eat bread and drink, at the age of 2 years he eats rice" (SP 5)

"I used to give my son honey when he is more 6 months, I mixed it with the milk so that his appetite increases, and he eats rice with fish" (SP 2)

"I gave my baby brown rice at the age of 6 months and over, while something like Sun porridge, I give it when my baby is at the age of 1 -year-old, and I never give him such infant formula. She used to breastfeed up to 5 times a day and ate porridge 3 times a day" (SP 4)

"At first I gave porridge, but when the baby was 9 months or older or almost a year, the baby did not want to eat porridge so I gave the baby rice" (SP 1 )

"When the baby was at the age of 7 months and above, I began to give him porridge but still with filter, then at the age of 1 year more I gave him ordinary porridge and at the age of 2 years I gave him rice" (SP 3 )

"The Posyandu also routinely give biscuit for 3 months and entered the last month they give an egg because it was brought by the Posyandu cadre" (SP 5)

"Recently, it was said that Posyandu also got some helps from Puskesmas (the health center), they give biscuits every week for 2 months and the last time they give egg mixed together with porridge as well" (SP 1)

"In Posyandu, it is usually given green bean porridge, but not often, sometimes if I go to Posyandu" (SP 4)

"But there has never been anything from the Puskesmas or Posyandu" (SP 2 )
I complain that my child preferred to eat snacks and lost appetite

I provide complementary foods consisting of carbohydrates, protein, and fat

I do not provide complementary foods consisting of carbohydrates, protein, and fat

I got exposed to the introduction an delivery of MP-ASI (complementary foods) balanced nutrition program from the Health Facility

I did not get exposed to the introduction and delivery of MP-ASI (complementary foods) balanced nutrition program from the Health Facility

\section{Table 5: Financial of family}

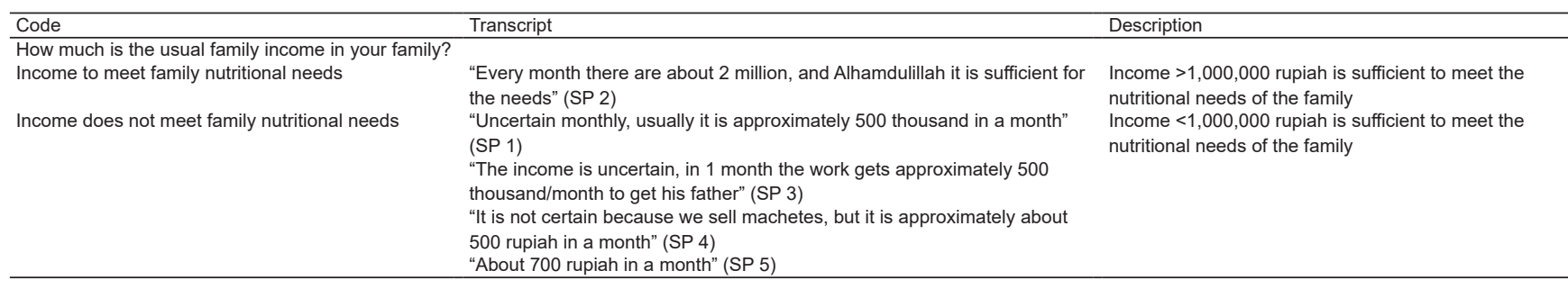


Table 6: Husband support to family

\begin{tabular}{|c|c|c|}
\hline Code & Transcript & Description \\
\hline \multicolumn{3}{|c|}{ How about daily expenses for family needs or other needs for your husband? } \\
\hline $\begin{array}{l}\text { The dominant income is used to meet } \\
\text { family needs on foods }\end{array}$ & $\begin{array}{l}\text { "More money is spent every day" (SP 1) } \\
\text { "Alhamdulillah, it is good enough to buy foods, because we have only } 2 \text { children. But for my needs, I } \\
\text { think about } 50,000 / \text { day, it does not include for other needs" (SP } 2 \text { ) } \\
\text { "Only for daily foods, but it is enough" (SP } 3 \text { ) } \\
\text { "Monthly income is more or less } 500 \text {, but that's enough money" (SP 4) } \\
\text { "That's the case, but it is good enough" (SP 5) }\end{array}$ & $\begin{array}{l}\text { Income is prioritized for daily food } \\
\text { consumption }\end{array}$ \\
\hline \multicolumn{3}{|l|}{ What is your husband's other needs? } \\
\hline $\begin{array}{l}\text { Expenditures that do not support family } \\
\text { nutrition }\end{array}$ & $\begin{array}{l}\text { "He smokes a half of pack per day, for the last } 5 \text { months he has stopped smoking because his neck } \\
\text { hurts" (SP 1) } \\
\text { "He smokes since before he married, he smoked it } 1 \text { pack/day" (SP 2) } \\
\text { "My husband also smokes, about } 1 \text { pack a day" (SP } 3 \text { ) } \\
\text { "He smokes often, one pack/day, and he always drinks coffee" (SP 4) } \\
\text { "My husband smokes, one pack a cigarette a day and he also drinks coffee beside the gasoline buyer it } \\
\text { is because he works" (SP 5) }\end{array}$ & $\begin{array}{l}\text { Income that can be used to meet } \\
\text { family nutritional needs is instead } \\
\text { used to consume things that can } \\
\text { interfere with family health }\end{array}$ \\
\hline \multicolumn{3}{|c|}{ Can you tell us about your husband's support that is usually given to your family or children? } \\
\hline $\begin{array}{l}\text { Husband supports in maintaining family } \\
\text { health }\end{array}$ & $\begin{array}{l}\text { "If my husband does not have time or suddenly gets sick, he used to ask people what medicine to take, } \\
\text { but he usually goes to ask people who know about jappi-jappi so it is not just medicine if our children } \\
\text { are sick. But if there is no medicine that is so normal he will take our child to the Puskesmas" (SP 1) } \\
\text { "If our children get sick, my husband thinks about what to do, commonly in here people usually look for } \\
\text { shamans to get water, or take them to regular Puskesmas or to the clinic, all support each other" (SP 2) } \\
\text { "Usually, if our children get sick, we give the sick water to drink. If the Posyandu schedule coincides, I } \\
\text { take my child there to be checked" (SP 3) } \\
\text { "My husband takes care of my sick child because he usually buys syrup for fever, moreover, my child is } \\
\text { often suffering from fever too" (SP 4) } \\
\text { "He supports, especially if the children are sick, he takes them to the Puskesmas too" (SP 5) }\end{array}$ & $\begin{array}{l}\text { My husband supports in } \\
\text { maintaining family health by taking } \\
\text { our children to the nearest health } \\
\text { facility }\end{array}$ \\
\hline \multicolumn{3}{|c|}{ How is the relationship between your husband toward your children in giving his support? } \\
\hline $\begin{array}{l}\text { The relationship between my husband } \\
\text { and children is good with sufficient } \\
\text { duration of communication }\end{array}$ & $\begin{array}{l}\text { "My son is closer to his father than me, he looks for his father more than me when he is about to sleep } \\
\text { because I usually get home at } 1 \text { or } 2 \text {, but when there is no activity at all, he is usually with his father. } \\
\text { Sometimes his father makes milk or it is usually his father who get meal for my child and feed him" } \\
\text { (SP 2) } \\
\text { "They often meet my husband usually go home late in the evening or at night. Usually, when my } \\
\text { husband gets home, he immediately pick up our child that's why our child is more familiar with his } \\
\text { father"(SP 3) } \\
\text { "My husband is close to all of our children, moreover, he often works at home or close to home, they are } \\
\text { just like friends let alone they sleep together at night" (SP 4) } \\
\text { "Yes, it is often after coming from work, and they also sleep together every night. Every time he gets } \\
\text { home after work, he always plays with your child, but sometimes my husband goes fishing" (SP 5) }\end{array}$ & $\begin{array}{l}\text { The relationship between my } \\
\text { husband and my children is well } \\
\text { established followed by sufficient } \\
\text { duration of communication for } \\
\text { the child }\end{array}$ \\
\hline $\begin{array}{l}\text { The relationship between my husband } \\
\text { and my children is good, they are just } \\
\text { lacking the duration of communication }\end{array}$ & $\begin{array}{l}\text { "It is good, they often communicate, but usually when my husband is busy he comes home at night, but } \\
\text { if not he usually takes a moment to go home at the break time around } 12 \text { O'clock" (SP 1) }\end{array}$ & $\begin{array}{l}\text { The relationship between my } \\
\text { husband and my children is well } \\
\text { established, they are just lacking at } \\
\text { the duration of communication }\end{array}$ \\
\hline
\end{tabular}

healthier and more independent. Income that can be used to meet family nutritional needs is instead used to consume things that can interfere with family health [25], [26].

\section{Theme 5: Husband support to family}

Table 6 show that income is prioritized for daily food consumption and the husband supports in maintaining family health by taking our children to the nearest health facility. The husband's support is crucial in stunting prevention efforts because the husband is a source of family income. Husbands need to be given additional knowledge about the dangers of smoking and the importance of using income in a more productive direction such as diverting cigarette consumption by buying nutritious food for the family [27].

On the other hand, the husband's support for the family is very good because they are ready to provide medicine for the child, take the child if they are sick to health services, and spend time with the child. The relationship between husband and children in the five families is very close, often playing with children, taking time to go home for lunch and meeting with children, and sleeping with children. This certainly can support the growth and development of children, but still, the husband must anticipate other factors, which is the provision of good nutrition for families, especially children

\section{Conclusion}

Mothers of children who are categorized as stunting do not have clear knowledge about stunting, apply exclusive breastfeeding for 6 months but breastfeeding is not optimal until 2 years of age, complementary feeding is not balanced because it does not consist of carbohydrate, protein, and fat sources, families with incomes below the minimum income experience stunting in their children. Husband's support to all participants is very good in overcoming health problems that occur in children, but her husband's support is very lacking in efforts to prevent children from experiencing stunting, mothers of children who are categorized as stunting have good personal hygiene behaviors in children. Based on this, it is suggested to improve health education about stunting, by introducing an easy-to-understand language and an interactive and sustainable counseling method. The introduction of complementary foods for breastfeeding should still be improved for families especially mothers to increase education about food replacement foods and families 
should prioritize the use of income for the supply of nutritious food.

\section{Acknowledgment}

Thank you to the Village Head, Health Cadre, and the mother of the stunting child of Pamboborang Village, Banggae Sub-District, Majene Regency, for helping with the collection of research data.

\section{References}

1. Winterfeld A. Improving child nutrition. NCSL Legisbrief 2010;18:1-2.

2. UNICEF. Malnutrition Rates Remain Alarming: Stunting is Declining too Slowly while Wasting Still Impacts the Lives of Far too Many Young Children, Tersedia Pada; 2019. Available from: https://www.data.unicef.org/topic/nutrition/malnutrition. [Last accessed 2020 May 20]

3. Kementerian Kesehatan Republik Indonesia. Profil Kesehatan Indonesia 2018 [Indonesia Health Profile 2018]. Indonesia: Kementerian Kesehatan Republik Indonesia; 2019. https://doi. org/10.7454/jki.v19i3.469

4. Indonesia KR. Data dan Informasi Profil Kesehatan Indonesia 2017. Indonesia: Kementerian Kesehatan Republik Indonesia; 2018. https://doi.org/10.7454/epidkes.v1i2.1806

5. Kementerian Kesehatan Republik Indonesia. Buletin Stunting. Vol. 301. Indonesia: Kementerian Kesehatan Republik Indonesia; 2018.p. 1163-78.

6. Suhardjo. Berbagai Cara Pendidikan Gizi. Jakarta: Bumi Aksara; 2003.

7. Millennium Challenge Account-Indonesia. Stunting dan Masa Depan Indonesia. Indonesia: Millennium Challenge Account-Indonesia; 2013. p. 2-5. https://doi.org/10.20473/ jgs.9.1.2015.123-140

8. Supariasa ID. Penilaian Status gizi (Edisi Revisi). Jakarta: Buku Kedokteran EGC; 2013.

9. Heriyanto H. Thematic Analysis Sebagai Metode Menganalisa Data untuk Penelitian Kualitatif. Anuva. 2018;2(3):317. https:// doi.org/10.14710/anuva.2.3.317-324

10. de Onis M, Branca F. Childhood stunting: A global perspective. Matern Child Nutr. 2020;12(Suppl 1):12-26. https://doi. org/10.1111/mcn.12231

PMid:27187907

11. Margawati A, Astuti AM. Pengetahuan ibu, pola makan dan status gizi pada anak stunting usia 1-5 tahun di Kelurahan Bangetayu, Kecamatan Genuk, Semarang. J Gizi Indones. 2018;6(2):82. https://doi.org/10.14710/jgi.6.2.82-89

12. Nasution SS, Oktavinola F, Hariati. Mother's knowledge dan attitude about stunting of children in Namorambe distric. ABDIMAS. 2019;4(1):61-5. https://doi.org/10.32734/ abdimastalenta.v4i1.2386

13. Nazri C, Yamazaki C, Kameo S, Herawati DM, Sekarwana N, Raksanagara A. Factors influencing mother's participation in Posyandu for improving nutritional status of children under-five in Aceh Utara district, Aceh province, Indonesia. BMC Public Health. 2020;16:69. https://doi.org/10.1186/s12889-016-2732-7 PMid:26801622

14. Hamel C, Enne J, Omer K, Ayara N, Yarima Y, Cockcroft A Childhood malnutrition is associated with maternal care during pregnancy and childbirth: A cross-sectional study in Bauchi and cross River States, Nigeria. J Public Health Res. 2020;4(1):5864. https://doi.org/10.4081/jphr.2015.408

15. Widayanti AW, Norris $P$, Green JA, Heydon S. Is expanding service through an outreach programme enough to improve immunisation uptake? A qualitative study in Indonesia. Global Public Health. 2020;15(8):1168-81. https://doi.org/10.1080/174 41692.2020.1751229

PMid:32290768

16. Destiadi A, Nindya TS, Sumarmi S. Frekuensi kunjungan posyandu dan riwayat kenaikan berat badan sebagai faktor risiko kejadian stunting pada anak usia 3-5 Tahun. Media Gizi Indones. 2015;10(1):71-5. https://doi.org/10.31227/osf.io/t4b26

17. World Health Organization. Global Strategy for Infant and Young Child Feeding. Geneva: World Health Organization; 2003.

18. Saeed OB, Haile ZT, Chertok IA. Association between exclusive breastfeeding and infant health outcomes in Pakistan. J Pediatr Nurs. 2020;50:e62-8. https://doi.org/10.1016/j. pedn.2019.12.004

PMid:31862130

19. Martorell R. Improved nutrition in the first 1000 days and adult human capital and health. Am J Hum Biol. 2017;29(2):1-24 https://doi.org/10.1002/ajhb.22952 PMid:28117514

20. Schwarzenberg SJ, Georgieff MK. Advocacy for improving nutrition in the first 1000 days to support childhood development and adult health. Pediatrics. 2018;141(2):e20173716. https:// doi.org/10.1542/peds.2017-3716

21. Lee KA, Bai Y, Wunderlich SM. A pilot study for plant the seed: $A$ nutrition education program using local food environment to put theory into action. Int J Sustain Dev Planning. 2016;11(6):102836. https://doi.org/10.2495/sdp-v11-n6-1028-1036

22. Utami RA, Setiawan A, Fitriyani P. Identifying causal risk factors for stunting in children under five years of age in South Jakarta, Indonesia. Enferm Clín. 2019;29:606-11. https://doi. org/10.1016/j.enfcli.2019.04.093 PMid:31311736

23. Laraia BA, Leak TM, Tester JM, Leung CW. Biobehaviora factors that shape nutrition in low-income populations: A narrative review. Am J Prevent Med. 2017;52(Suppl 2):S118-26. https://doi.org/10.1016/j.amepre.2016.08.003

24. Rahayu VI, Susanto N, Fitriani A. Determinant of stunting among children under five years old in Wukirsari Village, Cangkringan Subdistrict, Sleman, Yogyakarta. IImu Gizi Indones. 2019;3(1):53-8. https://doi.org/10.35842/ilgi.v3i1.127

25. Rahman N, Napirah MR, Nadila DB. Determinants of stunting among children in urban families in Palu, Indonesia. Pak J Nutr. 2017;16(10):750-6. https://doi.org/10.3923/pjn.2017.750.756

26. Caswell JA, Yaktine AL, Allotments $C$ on $E$ of the $A$ of $F R$ and S, Board F and N, Statistics C on N, Medicine I of, dkk. Individual, Household, and Environmental Factors Affecting Food Choices and Access. Supplemental Nutrition Assistance Program: Examining the Evidence to Define Benefit Adequacy. United States: National Academies Press; 2013. https://doi. org/10.17226/13485

27. Sumiati, Arsin AA, Syafar M. Determinants of stunting in children under five years of age in the Bone regency. Enferm Clín. 2020;30:371-4. https://doi.org/10.1016/j.enfcli.2019.10.103 PMid:32545090 